\title{
蚊幼虫の生物的防除のための数種粘液性 アブラナ科種子の効果
}

\author{
江下 優樹* 伊藤弘文** 栗 原 毅*

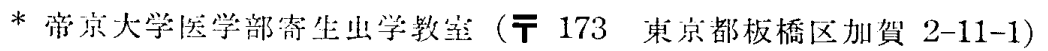 \\ ** 王川大学㕮学部昆虫学研究宣（干 194 東京都町田市玉川学園 6-1-1)
}

(受領：1978作：４月24日）

Effects of some mucilaginous plant seeds on mosquito larvae as a biological control agent

\author{
Yuuki Eshita,* Hirofumi ITO** and Takeshi KURIHARA* \\ * Department of Parasitology, Teikyo University School of Medicine, \\ Itabashi-ku, Tokyo 173, Japan \\ ** Laboratory of Entomology, Faculty of Agriculture, Tamagawa Uni- \\ iersity, Machida-shi, Tokyo 194, Japan
}

蚊の防除に天敵生物を利用することは，殺虫剤に代わ る，環境を污染しない方法として開発が期待されている (Anonymus, 1973)。その中でも, 魚類・線虫類など各 種捕食性あるいは寄生性動物が研究対象となってきた が，それらに対してアブラナ科植物の種子から分泌され る粘液 mucilage に着目して，種子を水中に投与し，幼 虫を付着させ殺す（Reeves and Garcia, 1969）という 方法は異色といえよう。この粘液の成分や性状について は, Reeves and Garcia (1969) の報告以降とくに検詰 が進み, 蚊幼虫捕捉には粘液中の cellulose や polysaccharideの含有物が重要で, 種子を加熱しても効果の でること(Barber et al., 1974，1976)，一部の粘液性種 子 mucilaginous seed 自体が蚊幼虫を誘引すること (Page and Barber, 1975) などが報告されている.

こうして，すでにアメリカで実験に供され検討されて きたものと類縁のアブラナ科植物は, 本邦にも多数栽培 または自生しているが，わが国ではまだその検討例にこ しい(栗原, 1974). そこで, 当教室の蚊天敵研究計画の 一環として，われわれは，本邦産のそれらが，同じよう な効果をもつか否か，また野外で蚊防除に利用するとし たらどのように種子を用いたらよいかについて検討を 加えた。

現所属: 謊苵ランド・キディ牧場生物研究室

\section{材料と方法}

供試種子はアブラナ科, 次の和名または商品名をもつ 栽培種 8 通りと, 野生種 6 種である.

栽培種（（）内は採種販売会社名, または採種地名） アブラナ Brassica campestris L. cv. Aburana (ピ ーコック)

ナタネ B. c. oleifera L. cv. Natane (東京・町田市) ヨリイカブ B. c. rapifera L. cv. Yorii-kabu（第一 園芸)

カナマチコカブ B. c. rapifera L. cv. Kanamachikokabu（トンボ）

コマチコカブ B. c. rapifera L. cv. Komachi-kokabu (ピーコック)

タイビョウヒカリカブ B. c. rapifera L. cv. Taibyohikarikabu（タキイ）

八ボタン B. oleracea var. acephala DC. cv. Habotan（東京・町田甫）

ミノワセダイコン Raphanus sativus L. cv. Minowase-daikon (ピーコック)

野生種 ( ( ) 内棌種地名)

ナズナ Capsella bursa-pastoris (L.)（東京・町田市） ヤマタネッタバナ Cardamine scutata Thunb.（神㴎 川県箱根) 
タネッケバナ C. flexuosa With. (東京・町田市)

ジャニンジン C. impatiens L.（箱根）

グンバイナズナ Thlaspi arvensa L. (東京・町田市)

イヌガラシ Rorippa indica (L.) (箱根)

これらの種子は, 植物体より採集後, 充分乾燥して発 牙能力をもつものである. 殺幼虫剤としての利用にあた り，雑草の繁殖を防止する意味で発芽力を削ぐ必要があ り，このため供試種子は，無処理と特記した場合を除 き， $120^{\circ} \mathrm{C} 20$ 分間の加熱高圧隇菌処理（以後熱処理と略 す）を施したものを実験に供している.

供試蚊は，継代飼育しているヒトスジシマカ Aedes albopictus (Skuse)（長崎産55 56 代， $25^{\circ} \mathrm{C} ， 16$ 時間照 明）で，卯孚化後 24 時間以内の 1 齢幼虫を，種子とともに 水中に投入した. すべての実験中の䬣は，乾燥ビール酵 母（エビオス薬品工業株式会社製）粉末を，幼虫 1 個体 あたり0.05mg の割合で，毎日 1 回投与した。すべての 実験は， $25 \sim 28^{\circ} \mathrm{C}$ で振動の加わることが少ない台上で 行なった.

実験 1 は, 前述14種のアブラナ科植物の種子から粘液 が分泌されるか否か，また，その厚さを調べた．各種類 別に種子10粒を，口径 $25 \mathrm{~mm}$ のシャーレに $6 \mathrm{ml}$ の蒸留 水とともに入れ，経時的に双眼実体顕微鏡下で粘液質の 厚さを，接眼ミクロメーターにより测定した。 なお，ナ タネについては，無処理の種子を比較に供した。

実験 2-1 は，実験 1 で粘液の 分泌が 認められた 5 種 の種子のおのおのに蚊幼虫が付着するか，またそれが致 死要因となるか否か比較した．口径 $55 \mathrm{~mm}$ のシャーレに $20 \mathrm{ml}$ の蒸留水を入れ，100個体の幼虫と 32 粒の種子を放 ち，24時間後に種子に付着している幼虫数を記録し，さ らに48時間，72時間後の死亡数を観察した。 ここでは， 無処理の種子も並行して比較した.

実験 2-2 では，供試種子の中で粘液層のもっとも厚い ヤマタネツケバナを用いて，種子の投与数と幼虫の付着 ならびに死亡数との関係を調べた， 口径 $55 \mathrm{~mm}$ のシャー レに $20 \mathrm{ml}$ の蒸留水とともに，2，8，32粒または 128 粒の種子を入れ，幼虫 100 個体を投入して 3 日閒飼育し た.この閒経時的に観察して, 種子に付着している幼虫 数およびその中で付着したまま死んでいる幼虫数を記録 した. 死亡幼虫は除去しないで放置した.

なお, 実験 2 に供した 5 種の種子の大きさ, 重量比な どについては Table 1 に示す.

\section{成 結}

\section{実験 1}

実験に 供した14種類の種子の中で，24時間浸漬して も, ナタネ, ヨリイカブ, ナズナ, ヤマタネッケバナ,

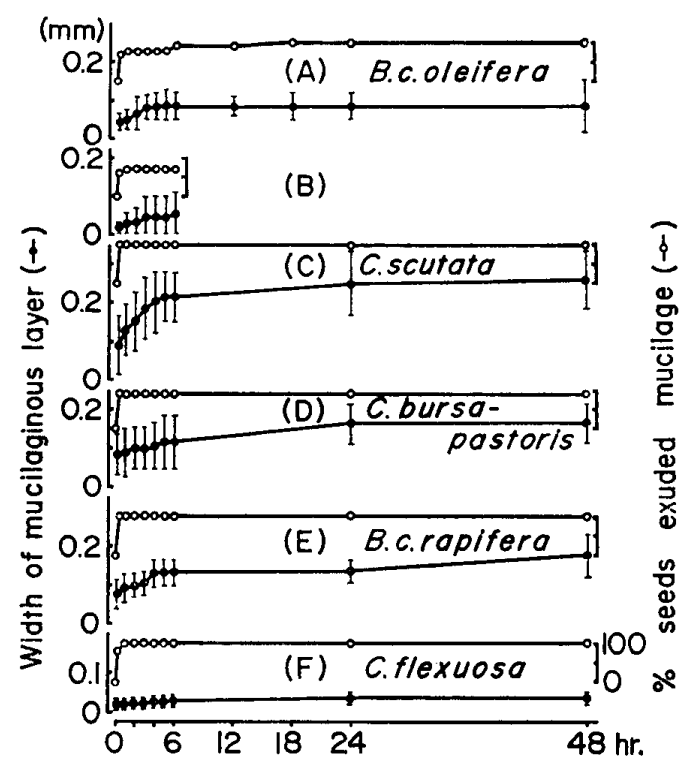

Fig. 1 Development of mucilaginous layer around plant seeds soaked in water Solid and open circles show width of the layer with $99 \%$ confidence interval, and the percentage of seeds produced the layer, respectively. The plant seeds examined were Brassica campestris oleifera cv. Natane in Japanese (A and B), Cardamine scutata (C), Capsella bursa-pastoris (D), B. c. rapifera cv. Yorii-kabu (E) and Cardamine flexuosa (F). All the seeds were heat-killed except B.

タネツケバナの 5 種以外のものは, 粘液の分泌を観察で きなかった. これに対して分泌を梕めた前述 5 種では, 水につけて直ちに, 種子を囲んでゼリ一様の粘液が分泌 され，6時間にわたって次第にその層を厚くし，24時間 でその厚みがほぼ安定した域に達した，Fig. 1は，無 処理のナタネと, 熱処理を行なった 5 種についてその層 の厚さを経時的に測定した成績である，粘液層は厚いも のから順に, ヤマタネッケバナ, ナズナ, ヨリイカブ, ナタネ，タネツケバナであった.

\section{実験 2-1}

粘液性種子 5 種類の幼虫付着状況を, 種子の大きさ, 重量，粘液層の厚さとともに Table 1 にまとめた。種 子 1 粒あたりの付着幼虫数は，4種とも平均 2 個体前後 であったが，とくに多いのはヤマタネツケバナで，その 最高は，1 粒の種子に13個体の幼虫が付着し，また24時 間後に無処理種子で77\%の付着率となった，付着率は粘 液層の厚いものに高率となる結果を示している。いずれ も無処理の種子の方が, 熱処理を行なった種子より付 着率が高い，しかし，タネツケバナは粒が小型で，粘液 層も他に比べ薄く，観察期間中にこれに付着した幼虫数 は，無処理のものでもゼロであった。 
Table 1 Size of the seeds, width of mucilaginous layers and percentage of larvae attached to 32 heat-killed seeds after 24 hrs soaking with 100 larvae

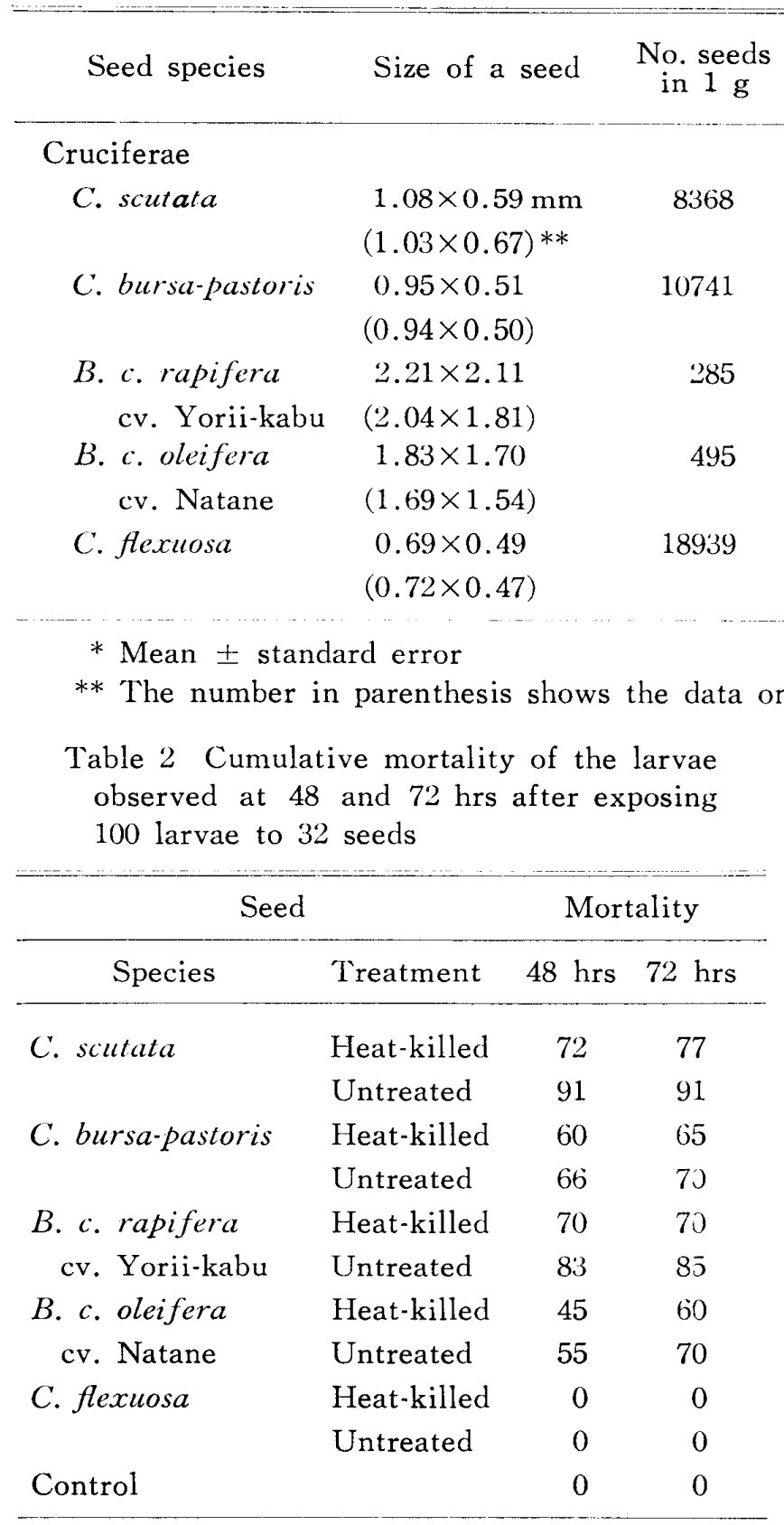

実験開始から24時間以降，これら容器は放置し，48時 間，72時間目に観察し，幼虫の累積死亡率を Table 2 にまとめた。 ヤマタネツケバナでは，すでに24時間経過 時に死亡幼虫を観察していたが，48時間以降ではタネッ ケバナを除いて，50\%以上の死亡率が認められた。無処 理のヤマタネツケバナが，死亡率でも高い值を示し，以 下死亡率は付着率の高いものほど高率となる傾向を示 寸。

\section{実験 2-2}

ヤマタネツケバナの種子の投入数別に, 各観察時に種 子に付着している幼虫総数と死亡幼虫数を記録した. 短 時間の間隔をへて観察をくり返しても，1度付着した幼

虫が種子から離れている現象が，しばしば認められた。 しかし，種子に付着する幼虫の頻度打よびその延べ数 は，種子の投入数が多いほど増加する傾问を示している (Table 3)。種子を多量に投入した場合には，24時間後 に種子に付着したまま死んでいる幼虫が認められるよう になり，とくに128粒の種子を入れた場合は，36时間後 に100個体の供試幼虫中，わずか 5 個体のみが自由に泳 ぎ，91個体が死んでいた，なお，この観察期間中，種子 を投大した容器では幼虫の死亡がみられたが，種子の入 っていないコントロール容器では, その死亡は認められ なかった。

\section{考察}

粘液性種子の殺幼虫効果は， Reeves and Garcia （1969）によりアブラナ科野生植物について認められ， その後シソ科植物 (Khan et al., 1974) にも同様な現象 が観察された，今回実験に供した中で，邦産の比較的入 手しやすい市販のアブラナ科植物であるナタネやヨリイ カブなど，栽培種にも粘液の分泌および殺幼虫効果が確 認されたことは，意義がある、ただ，この2種は，野生 種のヤマタネツケバナやナズナよりも効果が劣る。しか し，栽培種は種子の大量入手が可能なので，より選别を 重㸚たい，粘液性種子は，表皮細胞の厚く膨大した特徵 をもら，ショウゴインカブ Brassica rapa L. やテンノ ウジカブ B. rapa L. などもこのような特徽を備えてい る（猪野，1964）といわれるので，今後検討の対象とな ろう。ただここらは同一種のものでも，いわゆる地方 品種や栽培系統により，必ずしも同じ効果を示すとは限 らないので，邦産各地のものについて検討する必要があ 
Table 3 Number of larvae attached to the seeds at each of the observation times 100 larvae were reared for $72 \mathrm{hrs}$ with various numbers of the seeds of C. scutata

\begin{tabular}{|c|c|c|c|c|c|}
\hline \multirow{3}{*}{ Time after exposure } & \multicolumn{5}{|c|}{ No. seeds soaked } \\
\hline & \multicolumn{4}{|c|}{ C. scutata } & \multirow{2}{*}{$\frac{\text { control }}{0}$} \\
\hline & 2 & 8 & 32 & 128 & \\
\hline $2 \mathrm{hrs}$ & 2 & 56 & 68 & 81 & 0 \\
\hline 4 & 6 & 74 & 78 & 80 & 0 \\
\hline 6 & 7 & 71 & 83 & 78 & 0 \\
\hline 24 & 23 & 64 & $60(3)^{*}$ & $82(59)^{*}$ & 0 \\
\hline 36 & 16 & $76(15)^{*}$ & $73(55)$ & $95(91)$ & 0 \\
\hline 48 & $15(10) *$ & $76(62)$ & $75(72)$ & $92(91)$ & 0 \\
\hline 72 & $15(10)$ & $76(73)$ & $77(77)$ & $91(91)$ & 0 \\
\hline Total no. larvae died & 10 & 73 & 77 & 91 & 0 \\
\hline
\end{tabular}

* Cumulative no. of dead larvae out of the larvae attached to the seeds

ろう。本調査の発端は, 養蜂場のミツバチの水のみ場に 発生するヒトスジシマカを，殺虫片を使わずに殺す意図 にあった．前述のような栽培種から，この意図にかなっ た種子が見いだされれば，かなりの効果が期待されよ う.

熱処理種子が，無処理のそれより付着率が多少低下し たことは，今後処理法の改善が必要である。これらの種 子は，化学的に幼虫を誘引する効果があるといわれるの で (Barber et al., 1976), 誘引性を損わない処理法が必 要であろう。ただし今回観察した範囲では, 種子に付着 する幼虫の部位は，おもにその口器付近であり，また幼 虫注付着しても離脱することもあるので，この付着のメ カニズムについて検討する必要があると思われる。

粘液性種子の最終的評価は, 幼虫の死亡率であらわさ れる．ナズナには幼虫を殺す毒性はない (Supavarn $e t$ $a l ., 1974)$ ことから, 幼虫は行動を妨げられ呼吸困難で 死にいたると思われる. 処理後24時間頃から死婟体が 急速に増加することは，かなり長時間行動の自由を奪わ れた個体が死亡することを意味しょう。そして，今回の 実験から予測されたことは，種子は多数投入するほど効 果が大きいことであった。 Reeves and Garcia(1969) は， $1 \mathrm{~kg}$ の種子で殺しらる幼虫数により効果の表現を 試みているが, 幼虫の生息密度や対象蚊種によって, 適 切な必要量の算出法について検討することも必要であろ 5 .

\section{まと め}

本邦産アブラナ科植物 14 種類の種子の粘液性があるか どらかを調べたところ，5種にそれが認められた．粘液 層の厚い順に，ヤマタネッケバナ，ナズナ，ヨリイカブ,
ナタネ, タネツケバナであり，前 4 者に付着したヒトス ジシマカ幼虫の死亡率は，それぞれ $77 ， 65 ， 70 ， 60 \%$ と 高率であったが，粘液層のもっとも薄かったタネッケバ ナには，幼虫の付着も致死効果も認められなかった。 ヤ マタネッケバナ種子を蚊幼虬処理して 3 日間放置した ところ, 投与種子数の多いほど, 付着死亡する幼虫も多 くなる傾向が観察された。

\section{謝 辞}

玉川大学農学部阙田一次教授の类験上の御助言, 间 学部 杉本和永氏の種子採集と同定の御協力を感謝する。

\section{文献}

Anonymus (1973) : Mosquito control some perspective for developing countries, 63pp., National Academy of Science, Washington, D. C.

Barber, J. T., C. R. Page, III and A. S. Felsot (1974) : Interactions between mosquito larvae and mucilaginous plant seeds. I. Carbohydrate composition of mucilage in relation to the entrapment of larvae. Mosq. News, 34(4) : 394398.

Barber, J. T., C. R. Page, III, A. I. Berger and L. D. Hohenschutz (1976) : Interactions between mosquito larvae and mucilaginous plant seeds. III. Factors influencing attachment of larvae to seeds and their subsequent mortality. Mosq. News, 36(3) : 301-307.

猪野俊平 (1964)：植物組織学。604pp., 内田老鶴围 新社, 東京.

Khan, M. S., S. Waheed and S. H. Ashrafi (1974) : Effectiveness of some mucilaginous seeds as biological control agents for mosquito larvae. Pakistan J. Sci. Ind. Res., 17(4/5) : 
143-145.

栗原毅 (1974)：蚊の天敵。生活と環境，19(4)：2126.

Page, C. R., III and J. T. Barber (1975) : Interactions between mosquito larvae and mucilaginous plant seeds. II. Chemical attraction of larvae to seeds. Mosq. News, 35(1) : 47-54.

Reeves, E. L. and C. Garcia (1969) : Mucilaginous plant seeds of Cruciferae family as potential biological control for mosquito larvae. Mosq. News, 29(4) : 601-607.

Supavarn, P., F. W. Knapp and R. Sigafus (1974) : Biologically active plant extracts for control of mosquito larvae. Mosq. Neres, 34(4) : 398402 .

\section{Summary}

The seeds of 14 species, belonging to Cruciferae family, which are commonly available in
Japan, were observed for the exudation of mucilage in water and for the ability of trapping and killing Aedes albopictus larvae. The seeds of two cultured Cruciferae, Brassica campestris rapifera L. cv. Yorii-kabu in Japanese, and B. $c$. oleifera L. cv. Natane, as well as seeds of uncultured Cardamine scutata Thund, and $\mathrm{Ca}$ psella bursa-pastoris (L.) were proved to produce the mucilaginous layer and to trap and kill the larvae.

Thirty-two heat-killed seeds of the above four species were soaked in the water together with mosquito larvae. The percentage of larvae attached in 24 hours were 39, 47, 70 and $49 \%$, respectively. The mortality of these larvae in three days were $70,60,77$ and $65 \%$, respectively. Various numbers of seeds of C. scutata were soaked together with 100 larvae for three days. It has been shown that the mortality increased as the number of seeds soaked were increased. 